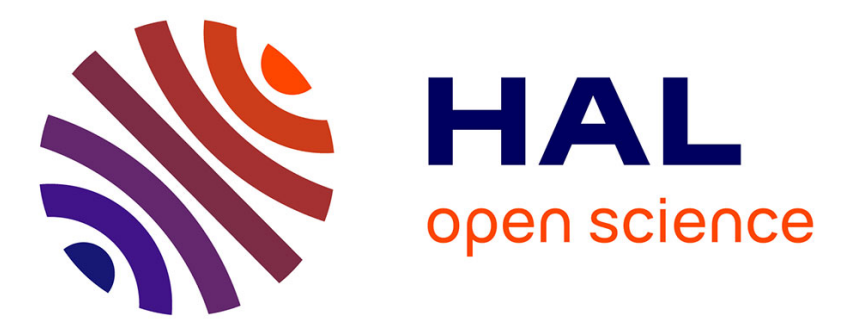

\title{
CLEAVAGE FRACTURE UNDER SHORT PULSE LOADING
}

\author{
H. Homma, Y. Kanto, K. Tanaka
}

\section{To cite this version:}

H. Homma, Y. Kanto, K. Tanaka. CLEAVAGE FRACTURE UNDER SHORT PULSE LOADING. Journal de Physique IV Proceedings, 1991, 01 (C3), pp.C3-589-C3-596. 10.1051/jp4:1991383 . jpa00250528

\section{HAL Id: jpa-00250528 https://hal.science/jpa-00250528}

Submitted on 1 Jan 1991

HAL is a multi-disciplinary open access archive for the deposit and dissemination of scientific research documents, whether they are published or not. The documents may come from teaching and research institutions in France or abroad, or from public or private research centers.
L'archive ouverte pluridisciplinaire HAL, est destinée au dépôt et à la diffusion de documents scientifiques de niveau recherche, publiés ou non, émanant des établissements d'enseignement et de recherche français ou étrangers, des laboratoires publics ou privés. 


\title{
CLEAVAGE FRACTURE UNDER SHORT PULSE LOADING
}

\author{
H. HOMMA, Y. KANTO and K. TANAKA \\ Department of Energy Engineering, Toyohashi University of \\ Technology, Tempaku-cho Toyohashi, 441, Japan
}

\begin{abstract}
Résumé: Des fissures dans l'acier SM50A pour structures soudées, trempé de -40 à $-160^{\circ} \mathrm{C}$, ont été créées pour différentes intensités de contraintes par impulsion d'une durée de 20,40 et $80 \mu$ s pour générer les données expérimentales sur les niveaux d'intensité de contraintes critiques pour l'instabilité de fracture . Les surfaces de fractures ont été observées par microscopie électronique à balayage afin d'examiner l'origine de la nucléation des clivages à l'avant des pointes de fissures. Les résultats expérimentaux obtenus sont discutés à partir du critère de temps minimal et de la plasticité à la pointe de la fissure.
\end{abstract}

Cracks in SM50A, steel for welding structure chilled at -40 to $-160 \mathrm{C}$ were loaded by various stress intensj.ty pulses with durations of 20 , 40 , and $80 \mu s$ to generate experimental data of critical stress intensity levels for crack instability. Fracture surfaces were observed by a scanning electron microscope to examjne cleavage nucleation origins ahead of the crack tips.

The obtained experimental results were discussed from the minimum time criterion and the crack tip plasticity.

\section{INTRODUCTION}

Crack instability is strongly affected by loading rate and test temperature especially in body-centered cubic metaliic materials as low carbon steel. ASTM standard E399 provides a test method for fracture toughness measurement under rapid loading. However, there is a restriction of loading rate so that stress field in a specimen could remain to be quasi-static.

For the very rapid loading under which the stress field near a crack tip is significantly affected by inertia, we lack reliable crack instability criteria and experimental data. The crack instability criteria proposed heretofore are classified to two types. One of them is based on the quasi-static concept that a crack becomes unstable immediately when a fracture parameter evaluated by fully dynamic analysis equals or exceeds the critical value[1,2]. The other takes into account of time effect that the crack instability is brought about when the fracture parameter equals or exceeds the critical value for a certain period $[3,4,5]$. The period is called "minimum time" or "incubation time". In the previous work, values of the minimum time 
for the steel for welding structure, SM50A(Japanese Industrial. Standards) at $-40 \mathrm{C}$ and $-80 \mathrm{C}$ were obtained[6]. The aims of this work are to generate experimental data of crack instability at lower temperature than $-80 \mathrm{C}$ and to examine the minimum time criterion for sleavage fracture in steel at the low temperature with crack tip plasticity.

\section{EXPERIMENTAL PROCEDURES}

\subsection{Material and Specimens}

Material used in the experiment was the steel for welding structure SM50A and its chemical composition and mechanical properties are indicated in Table 1. Three kinds of specimen configurations shown in Fig. 1 were prepared to generate $80 \mu \mathrm{s}, 40 \mu \mathrm{s}$ and $20 \mu \mathrm{s}$ duration stress intensity histories when the specimen was loaded by one point bending [7].

Table 1. Chemical composition and mechanical properties

(b) mechanical properties

(a) chemical composition

\begin{tabular}{|c|c|c|c|c|c|c|}
\hline Material & $\mathrm{C}$ & $\mathrm{Si}$ & $\mathrm{Mn}$ & $\mathrm{P}$ & $\mathrm{S}$ & $\mathrm{Fe}$ \\
\hline SMSOA & $<0.2$ & $<0.55$ & $<1.5$ & $<0.04$ & $<0.04$ & $\mathrm{Re}$. \\
\hline
\end{tabular}

\begin{tabular}{|c|c|c|c|c|c|}
\hline Material & $\begin{array}{c}\text { Yield } \\
\text { Point }\end{array}$ & $\begin{array}{c}\text { Tensile } \\
\text { Strength }\end{array}$ & Elongation & $\begin{array}{c}\text { Sirain } \\
\text { n.e }\end{array}$ & $\begin{array}{c}\text { Yewas } \\
\text { Mcuvilus }\end{array}$ \\
\hline Unit & MPa) & (MPa) & $(\%)$ & $(n)$ & $($ MPa) \\
\hline SM50A & 422 & 588 & 31 & 0.25 & 206000 \\
\hline
\end{tabular}

Test temperatures were $-120 \mathrm{C}$ and-160 $\mathrm{C}$ which are much lower than the transition temperature of the steel so that the whole fracture surface would be covered by cleavage.

\subsection{Loading Device and Measurement of Dynamic Stress Intensity Histoires}

The loading device is shown in Fig.2. The projectjle was launched by opening the solenoid valve. The pressurized gas flew into the barrel at a high speed and pushed the projectije to accelerate it against the load transfer rod contacting with the mjd-point of a specimen. The specimen was loaded by one point bending due to the transmitted stress wave from the rod since the specimen had no supports. Impacl velocity was controlled by the gas pressure.

Dynamic stress intensity history experienced by a crack was measured by a strain gage mounted $7 \mathrm{~mm}$ far from the crack tip according to the method developed by Dally and Sanford[8]. 
3. RESULTS

3.1 Critical Stress Intensity for Crack Growth

The maximum value of dynamic stress intensity pulse measured by the strain gage method is plotted against the pulse duration as a parameter of crack growth event in Fig. 3 for the test temperature of $-120 \mathrm{C}$ and $160 \mathrm{C}$. Each data was obtained for one specimen.

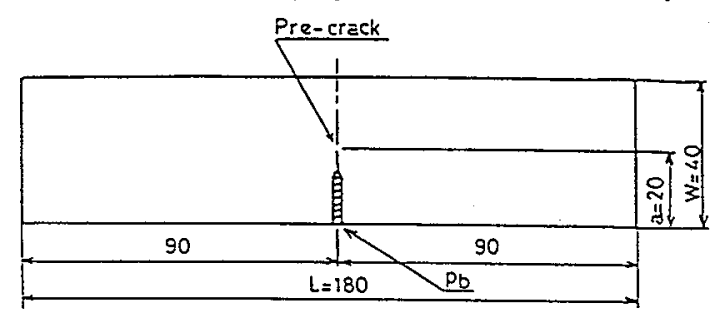

The open circle means that the crack did not grow under the stress intensity pulse and the solid circle means that the crack grew under the pulse. A critical value of dynamic stress intensity for

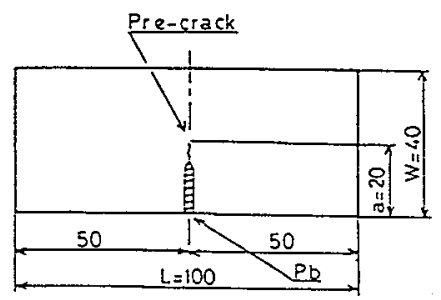
the crack initiation was defined as the middle of the adjacent solid and open circles. The critical value is shown as a function of the stress intensity pulse duration in Fig.4 including the previous results at $-40 \mathrm{C}$ and $-80 \quad \mathrm{C}[6]$.

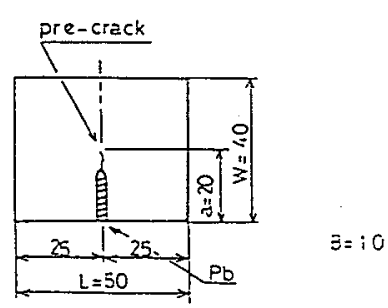

Fig.1. Specimen configuration

It is indicated that the critical values for 40 and $80 \mu \mathrm{s}$ durations are almost same and those are much smaller than the value for 20 us duration. It

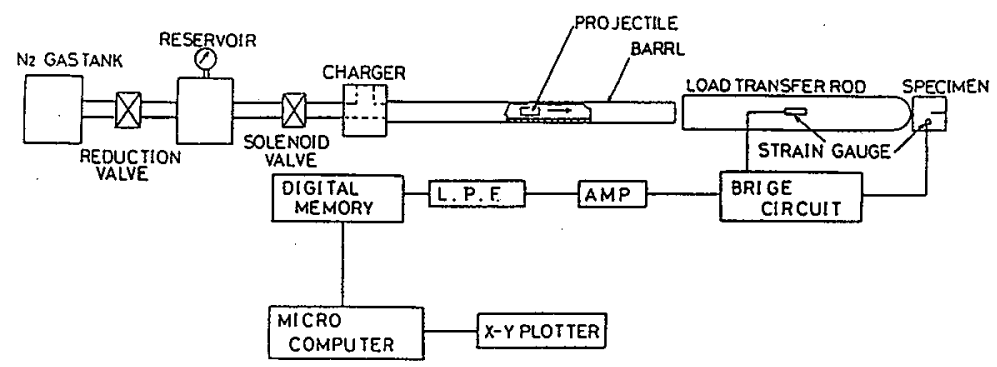

Fig.2. Loaciing device

is also seen that

there is temperature dependence of the critical value.

\subsection{Observation of Cleavage Fracture}

Fracture surface near the initial crack tip was observed by a scanning electron microscope. For all the experimental conditions, the whole of fracture surface was covered by the cleavage. The cleavage was 
always nucleated ahead of the initial crack tip. The nucleation origin can be detected by tracing back flow direction of river patterns to the flow origin. The origin was a flat and smooth facet, and its direction almost

equaled the macro-scopic fracture surface direction.

The distance between the initial crack tip and the nucleation origin was measured and is shown as a function of the temperature in Fig.5. It was noticed that the nucleation origin was almost independent of the pulse duration while it is significantly dependent on the test temperature higher than $-120 \mathrm{C}$ as shown in the figure.

\section{DISCUSSION}

The critical maximum value of dynamic stress intensity pulse significantly increased at the duration of $20 \mu \mathrm{s}$ as shown in Fig.4. The steep increase is well explained from the minimum time criterion[3]. The critical stress intensity determined by the minimum time criterion is shown as a function of the test temperature in Fig.6. It is seen that the temperature effect is significant in the range of higher than $-120 \mathrm{C}$. The nucleation origin of the clectvage will be considered

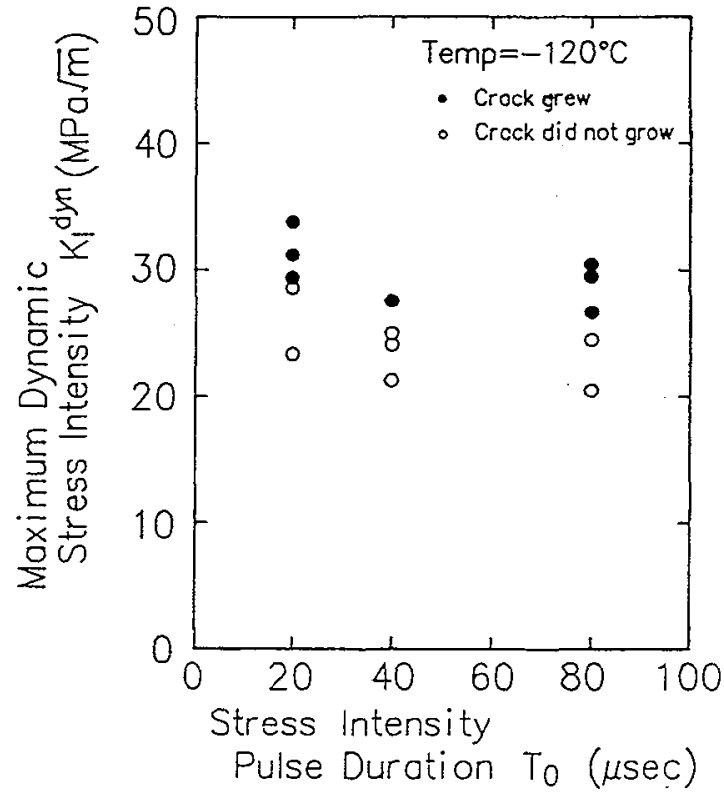

Fig.3. Maximum stress intensity for crack initiation as a function of pulse duration

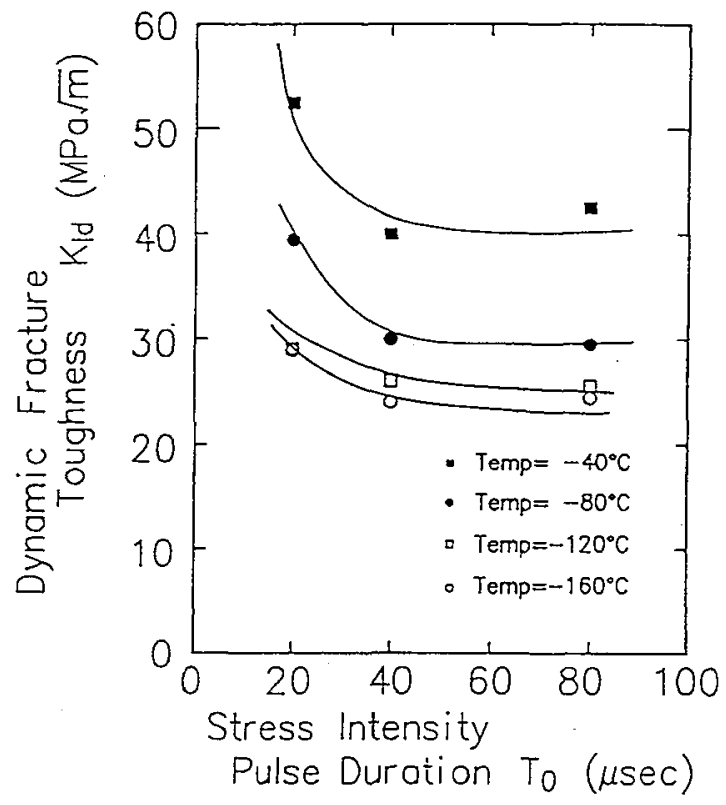

Fig.4. Critical stress intensity for crack initiation as a function of pulse duration 
in association with the plastic zone. Dynamic yield strength of the material was estimated by the equation given in ASTM standard E399 Annex 7. The dynamic yield strength was indicated in Table 2 for $80 \mathrm{\mu s}$ duration pulse. The calculated plastic zone size is listed in Table 2. Comparing these results with the nucleation origin of cleavage fracture, it is seen that the cleavage fracture was initiated 1 to 2 times of the plastic zone size far from the initial crack tip. Since average grain diameter of the used steel is around $50 \mathrm{~mm}$, only one or three

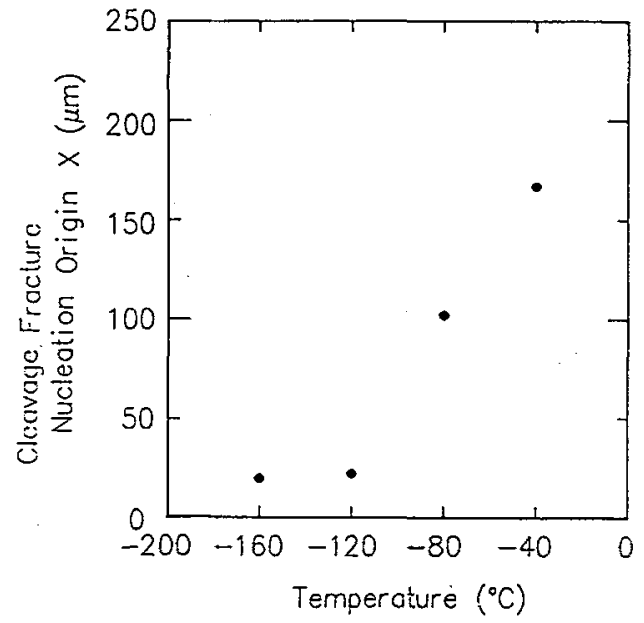

Fig.5. Cleavage fractre nucleation origin as a function of temperature grains will exist in the plastic zone. The cleavage was nucleated at one to three grains ahead of the crack tip. Fipecially, the cleavage fracture at the temperature of lower than $-120 \mathrm{C}$ was nucleated in the grain adjacent to the crack tip of which the cleavage plane was approximately parallel to the macro-scopic fracture surface. When the crack was loaded by the critical stress intensity, the elastic stress at the nucleation origin can be calculated by

$$
\sigma=\frac{K}{\sqrt{2 \pi r}}
$$

The calculated stress is also indicated in Table 2. It is seen that the elastic stresses for -120 $\mathrm{C}$ and $-160 \mathrm{C}$ are equal to each other and are around twice as large as those for $-40 \mathrm{C}$ and $-80 \mathrm{C}$.

Hahn et al[9] reviewed the proposed several dislocation models for the cleavage Table 2. Dynamic yield strength, and plastic zone size, nucleation origin arid elastic stress.

fracture and explained their experimental data using a disjocation model. In all the dislocation 
models, the cleavage fracture is initiated by the pile-up of dislocations against an obstacle such as the grain boundary and inclusions. In this experiment, dislocations were emanated from the crack tip and piled up at the nucleation origin. Stress concentration ahead of the pile up of the dislocations is approximately proportional to the number of the pijed dislocations if the static equilibrium is kept. The calculated elastic stress at the nucleation origin may be enhanced to the cleavage stress by the stress concentration due to the piled dislocations. Namely,

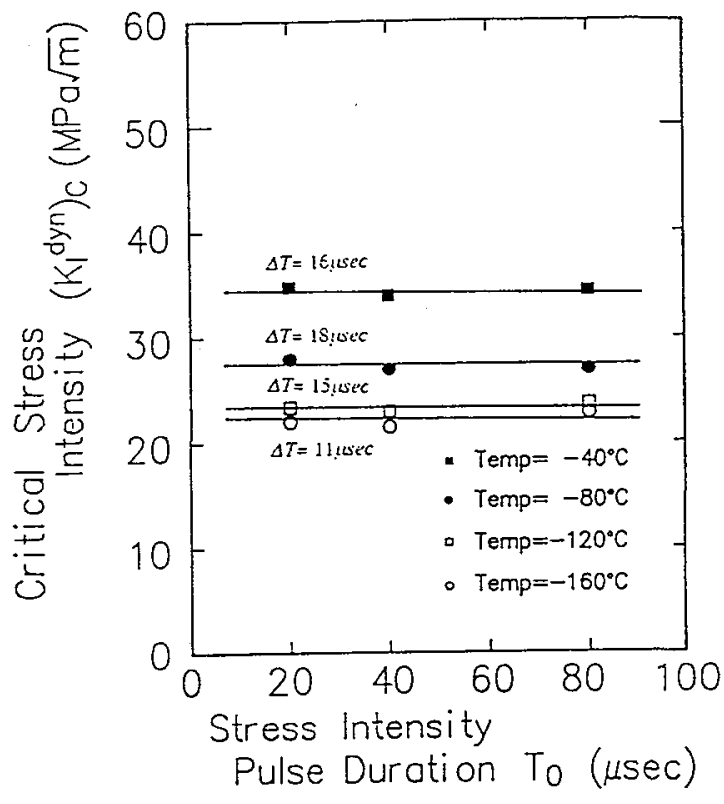

Fig.6. Critical stress intensity for crack initiation as a function of tem perature

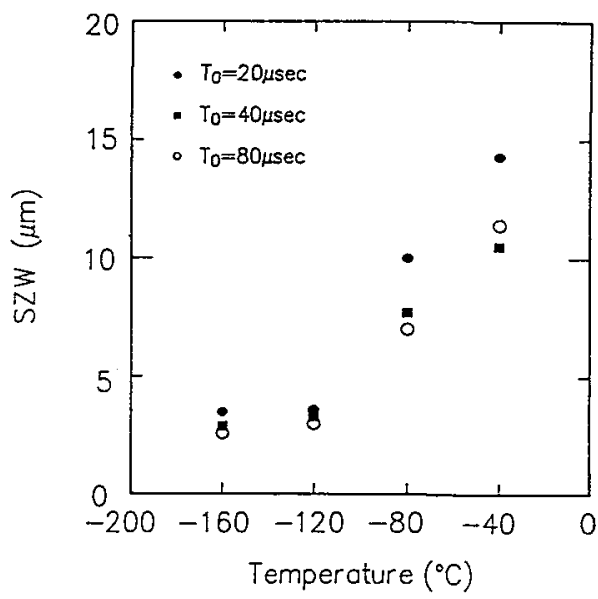

Fig.7. Stretched zone width as a function of temperature

that the values of $\mathrm{szw}$ at -120 and

$-160 \mathrm{C}$ are almost equal and that

the value of szw at $-80 \mathrm{C}$ is around twice as large as those at -120 and 
$-160 \mathrm{C}$. The szw for $20 \mu \mathrm{s}$ duration at $-40 \mathrm{C}$ and $-80 \mathrm{C}$ was relatively larger than those for $40 \mathrm{\mu s}$ and $80 \mu \mathrm{s}$ durations. Ihis can be understood if it is considered that movement of dislocations emanated near the instance of the crack initiation is not ceased, so that the static equilibrium is not kept and that the static non-equilibrium state is more enhanced under higher loading rate to emanate the dislocations more and to blunt whe crack tip more.

\section{CONCLUS IONS}

Experiments on crack instability under short pulse loading were made at low temperatures of -120 and -160 C usjng steel for welding structure SM50A so that cleavage fracture would predominantly take place at, the crack initiation. The following conciusions were obtained:

1. The maximum stress intensity experienced by a crack at the crack instability was much larger for 20 us-duration stress intensity pulse than for 40 and $80 \mu$ s-duration stress intensity pulses. jhjs was well explained by the minimum time criterion.

2. The cleavage fracture nucleation origins were around $20 \mathrm{~mm}$ far from the initial crack tip for the both temperatures while those were around 170 and $100 \mathrm{~mm}$ for -40 and $-80 \mathrm{C}$ respectively.

3. The stretched zone size at the initial crack tip coujd be well explained qualitatively from the calculated ejastic stress at the cleavage nucleation origin and the dislocation dynamics.

\section{REFERENCES}

[1]Achenbach, J.D. and Brock, L.M. (1973). in Dynamic Crack Propagation, G.C. Sih,Ed., Noordhoff, The Netherlands, p.529

[2]Lehnigk,S.H.(1973). in Dynamic Crack Propagation, G.C. Sih, Ed., Noordhoff, The Netherlands, p. 333

[3]Kalthoff,J.F. and Shockey, D.A. (1977). Journal of Applied Physics, $43-3$, p. 986

[4]Homma,H., Shockey,D.A., and Murayama,Y.(1983). Journa! of the

Mechanics and Physics of Solids, 31-3, p.261

[5]Kalthoff,J.F.(1986). Engineering Hracture Mechanics, 23-1, p.289

[6]Homma, H., Kanto, Y and Tanaka,K.(1990). To appear on ASTM STP for the proceedings of symposium on "Rapid Joad Fracture lesting" April 22-27 1990, San Francisco USA

[7]Bohme, W. and Kalthoff,J.F. (1982). International Journal of Fracture, $20-1, p .139$

[8]Dally,J.W. and Sanford, R.J.(1987). Experimental Yechanics,27-4. 
p. 381

[9]Hahn, G.'T., Averbach, B.L., Owen, W.S., and Cohen.M. (1959). in Fracture, Averbach et al Ed., The M.I.T. Press, USA, p. .I 